\section{Environmental Regulations, Green Innovation and Performance: An Analysis of Industrial Sector Companies from Developed Countries and Emerging Countries}

\author{
Jaluza Maria Lima Silva Borsatto ${ }^{1}$ \\ jaluzasilva@yahoo.com.br| (DD) 0000-0002-8852-4583 \\ Camila Bazani ${ }^{1}$ \\ camilabazani@ufu.br | (D) 0000-0001-6603-4471 \\ Lara $\mathrm{Amui}^{2}$ \\ lara.liboni@gmail.com | (1) 0000-0002-4729-7943
}

\section{ABSTRACT}

This study analyzes whether the rigor of environmental regulations encourages industrial companies in developed and emerging countries to invest in Green Innovation (GI), and what is the impact on financial performance. The sample was composed of 159 industrial companies, listed in the Financial Times' 500 largest companies by market value in 2015. For the analysis, Structural Equation Modeling was used to verify the relationship between the variables. The main results were that the strictness of the countries' environmental regulations, and the size of the companies had a statistically significant positive impact only on construct GI2, composed of the variables Global Compact and environmental investments. Countries competitiveness did not positively influence companies' GI efforts, and the degree of internationalization of companies had no significant effect on any of the GI constructs. Furthermore, the efforts of companies in GI do not reflect positively on their financial performance.

\section{KEYWORDS}

Green Innovation, Financial Performance, Environmental Regulations, Institutional Environment, Structural Equation Modeling
${ }^{1}$ Universidade Federal de Uberlândia, Uberlândia, MG, Brasil

${ }^{2}$ Universidade de São Paulo, Ribeirão Preto, SP, Brasil

Received: 10/30/2019.

Revised: $11 / 18 / 2019$.

Accepted: 02/05/2020.

Published Online: 07/27/2020

DOI: http://dx.doi.org/10.15728/bbr.2020.17.5.5 


\section{INTRODUCTION}

Staying global and economically competitive in the market has become a constant challenge for organizations, given the intensification of changes in social, political, economic, and technological conditions that have resulted in different consumer demands. In addition, awareness about reducing impacts on the environment and preserving the planet has become a relevant topic in recent decades (Cai et al., 2017). In this scenario, Porter (1989) argues about the need to adopt a sustainable strategy in order to obtain a competitive advantage and stand out from competitors.

For Porter (1989), competitive advantage is associated with innovation as organizations perceive ways to compete better in the market. For Mintzberg et al. (2003) innovation consists of breaking with established standards. Davila, Epstein and Shelton (2006) assert that, in the long run, only the ability to innovate better and continuously can guarantee the survival of a company.

Connected to innovation, the concern with environmental issues has become an important factor for organizations. Pujari (2006) guarantees that the debate regarding practices involving environmental and sustainable issues is growing. There is a greater pressure on the part of consumers, who began to demand environmentally correct and sustainable conduct from organizations. In addition, it is emphasized that laws concerning environmental practices can be considered fundamental when considering the decision of organizations in the adoption of innovation activities (Arenhardt, Battistella, \& Franchi, 2012).

Thus, considering an increasingly competitive scenario, under the trend of strict environmental protection regulations and conventions, as well as the rise of international consumer environmentalism, companies must now be able to invest in the environment and remain profitable to meet the needs of shareholders. Furthermore, they must seek sustainable practices and innovations that bring environmental, social and economic benefits.

Under Porter's hypothesis, Porter and van der Linde (1995) sought to present how environmental performance can contribute to obtaining a competitive advantage on the part of companies and nations. The authors assure that if the environmental regulation is properly elaborated and applied, it will benefit the company and the environment by stimulating innovation. Thus, strict environmental regulation encourages companies to seek innovations to reduce the cost of improving environmental impact, increasing their competitiveness. According to Gordon and McCann (2005), the definition of innovation is not simple, in view of the fact that it is a term widely used in several contexts.

In this scenario of fierce competition, the concept of Green Innovation arises. For Dangelico and Pujari (2010), the term Green Innovation is used to refer to efforts in search of environmental protection, conservation of energy and resources and also the reduction or

elimination of toxicity, pollution, and waste. According to Chen, Lai, and Wen (2006), it consists of innovations in products and processes in which energy savings, pollution prevention, waste recycling, and environmental management are sought.

Dangelico and Pujari (2010) state that, although no product has a zero impact on the environment, the practice of Green Innovation can be considered one of the key factors to simultaneously improve companies' environmental, social, and financial results. However, Link and Naveh (2006) stated that investments in Green Innovation do not always result in high financial performance by companies. Gauthier and Wooldridge (2012) consider that the financial benefits from sustainable innovation are still uncertain and divergent. 
In the literature, the number of studies that address the relationship between Green Innovation and the performance of companies has increased, but the results are still contradictory (Ar, 2012; Arenhardt et al., 2012; Lin, Tan, \& Geng, 2012; Aguilera-Caracuel; Ortiz-de-Mandojana, 2013; Ghisetti \& Rennings, 2014; Li, 2014; Przychodzen \& Przychodzen, 2015; Xie et al., 2015). These inconsistencies may be related to the methodology used, the context of the countries, the sector analyzed, the theory used, and other factors.

Several studies on Green Innovation have used Institutional Theory as a reference, seeking to explain the relationship between institutional pressures on companies' sustainable actions (Seles et al., 2016; Dubey et al., 2017; Rentizelas et al., 2020; Borsatto \& Amui, 2018). However, when seeking to complement the arguments of DiMaggio and Powell (1983), Scott (2001) presented neo-institutional proposals where external pressures can affect the diffusion and development of institutional norms and practices through operational innovations.

In this context, and considering that this study will address environmental regulations and the competitiveness of countries as a backdrop for Green Innovation in companies, and analyze the financial consequences of environmental management practices, the Neoinstitutional Theory will be used as a reference. According to Ntim and Soobaroven (2013), the Neoinstitutional Theory suggests that institutional forces, such as political, economic and social institutions, can lead or shape a company's involvement with social and environmental performance. In addition, Neoinstitutional Theory predicts that a company's response to institutional pressures is usually motivated by legitimacy and efficiency. Through legitimation, companies can fulfill institutional pressures by adopting corporate social strategies that can help them obtain, maintain and defend organizational legitimacy (Ntim, 2016). For efficiency, companies can become substantially involved in social and environmental practices in order to protect the interests of shareholders and to improve financial performance (Aguilera et al., 2007).

Recognizing the importance of the relationship between environmental regulations and competitiveness on the environmental management of companies in developed and developing countries, and the contradiction of the results of studies on the subject, the question that guides this research is: what is the relationship between the degree of severity of environmental regulations and the international competitiveness of countries with efforts in Green Innovation and the financial performance of companies in the industrial sector in developed and developing countries?

Thus, based on the neoinstitutional theory, the main objective of this research is to analyze the relationship between the degree of severity of environmental regulations and the international competitiveness of countries with efforts in Green Innovation (GI) and the financial performance of companies in the industrial sector of developed countries (DC) and emerging countries (EC).

The results showed that the strictness of the countries' environmental regulations and the size of the companies had a positive impact on construct $\mathrm{GI}_{2}$, composed of the variables Global Compact and Environmental Investments. However, the competitiveness of countries and the degree of internationalization of companies did not have significant effects on any of the IV constructs. In addition, companies' Green Innovation efforts have not had a positive impact on financial performance, differing from what has been presented in the literature.

In view of the divergences in the results presented in the literature, which can be complemented by this study, it is expected that this research can contribute by shedding light on a "counterdiscussion” on Green Innovation and its relations with environmental regulations and financial performance, as has been approached by other authors (Lee \& Min, 2015; Dangelico, 2016). From a managerial point of view, this study suggests that the rigor of environmental regulations 
still shapes decisions in relation to environmental investments and voluntary sustainability actions, which, in a certain way, helps the company's image in the market, but does not reflect on financial performance.

\section{LITERATURE REVIEW AND HYPOTHESIS DEVELOPMENT}

The search for sustainable development by institutions, companies, and nations has been emphasized in recent years (Herciu \& Ogrean, 2014). For the aforementioned authors, sustainable competitiveness is the goal of all economies. According to Balkyte and Tvaronaviciene (2010), competitiveness must be supported by a broad view of the economy and society. In this scenario, the adoption of environmental practices by companies has become a factor of relevance and growing interest among scholars (Gauthier \& Wooldridge, 2012).

Currently, the discussion about sustainability runs through a development model that focuses on strategies that encompass, in addition to environmental preservation practices,

economic growth and social participation. This model is called the Triple-Bottom Line or Sustainability Tripod, and it causes a paradigm shift on the part of companies who, in search of sustainable development, must now be aware of the three dimensions of this model: environmental, economic, and social.

For Carpes et al. (2012), the understanding of this model can be summarized under the conception that companies can obtain financial return without undue exploitation of natural resources and the oppression of workers. Herciu and Ogrean (2014) state that it is the synergy between economic, social, and environmental developments that will create sustainable competitiveness for nations. According to Barbieri et al. (2010), it is considerable to show that sustainable development, in addition to encompassing the three dimensions mentioned in the Triple-Bottom Line, requires substantial innovation, developing important strategies, and contributing to national and international economic policies.

For Lustosa (2010), preserving the environment is a differentiating factor in a competitive process of companies and including environmental concerns in their strategies has become a possibility. Such differentiation permeates the innovation process. The literature addresses that investments in Green Innovation lead to increased competitiveness. Apak and Atay (2015) affirm that Green Innovation is an important tool for obtaining an international competitive advantage in global markets. Podcameni (2007) identified that the adoption of environmental innovations indirectly reinforces the competitive performance of companies.

Several studies show that companies are under severe pressure from environmental regulations to adopt environmental practices (Doran and Ryan, 2012; Li, 2014; Zailani, 2015; Liu et al. 2017). Zhu and Sarkis (2007) identified that the existence of market and regulatory pressures influences organizations to have better environmental performance. Sarkis et al. (2010) contributed to the literature by presenting that the pressure from interested parties and the dimensions of dynamic capabilities are complementary theoretical structures. Porter and van der Linde (1995) assert that the new paradigm of global competitiveness requires the ability to innovate quickly. In this paradigm, the authors argue about the profound implications for environmental policies and consider that these policies are favorable to innovation and stimulate environmental innovation practices by companies.

However, these results can be contrasted, considering the existence of studies that had contrary findings, that is, that the regulations do not directly affect the posture for the adoption of 
environmental practices by companies (Zhu and Geng, 2013; Lin et al., 2014; Ren et al., 2018). Bernauer et al. (2006) state that the effects of environmental regulation on innovation are still considered inconclusive and contested. Eiadat et al. (2008), when examining the links between the adoption of an environmental innovation strategy and the business performance of companies in Jordan's chemical industry, found that the adoption of an environmental innovation strategy is influenced by certain forces of environmental pressure. In view of the above, the following hypotheses were established:

- H1a: Environmental regulations are positively related to the Green Innovation $\left(\mathrm{GI}_{1}\right)$ effort of companies in the industrial sector of DC and EC.

- H1b: Environmental regulations are positively related to the Green Innovation $\left(\mathrm{GI}_{2}\right)$ effort of companies in the industrial sector of DC and EC.

- Hza: Countries' competitiveness is positively related to the Green Innovation $\left(\mathrm{GI}_{1}\right)$ effort of companies in the industrial sector of the DC and EC.

- Hzb: Countries' competitiveness is positively related to the Green Innovation $\left(\mathrm{GI}_{2}\right)$ effort of companies in the industrial sector of the DC and EC.

Other studies discuss the size of companies as a determining factor for adopting environmental practices. Podcameni (2007) identified that the companies that tend to adopt more environmental innovations are large companies. Wang and Song (2017) verified that the size of the company and the type of ownership potentially affect green technological progress. According to the authors, state or foreign companies with a high level of income pay greater attention to environmental issues. Zhu and Sarkis (2007), when analyzing the Chinese industry, found that the implementation of environmental practices occurred with the objective of meeting the demand for exports and sales to foreign customers. Thus, hypotheses 3 and 4 are proposed:

- Hзa: The size of companies in the industrial sector of the DC and EC are positively related to the Green Innovation effort $\left(\mathrm{GI}_{1}\right)$.

- Hзb: The size of companies in the industrial sector of DC and EC are positively related to the Green Innovation effort $\left(\mathrm{GI}_{2}\right)$.

- H4a: The degree of internationalization of companies in the industrial sector of the DC and EC are positively related to the Green Innovation effort $\left(\mathrm{GI}_{1}\right)$.

- H4b: The degree of internationalization of companies in the industrial sector of the DC and EC are positively related to the Green Innovation effort $\left(\mathrm{GI}_{2}\right)$.

Balkyte and Tvaronaviciene (2010) expound on the need to develop sustainable competitiveness based on theoretical models that describe the relationships between international globalization, economic growth, sustainable development, well-being, and competitiveness.

Barbieri et al. (2010) state that Green Innovation contributes both to economic development and to the preservation of the environment, being, therefore, a key element towards more sustainable development. Zailani et al. (2015) found that Green Innovation has a positive effect on the three dimensions of the Sustainability Tripod.

Doran and Ryan (2012), based on the theory of Porter and van der Linde (1995), found that eco-innovation is considered more important than non-eco-innovation in determining the 
company's performance. Li (2014) found that the effect on companies' financial performance occurs through the mediating role of environmental performance. Aguilera-Caracuel and Ortiz-de Mandojana (2013) found that companies that adopt Green Innovation have a positive relationship between the intensity of Green Innovation and the company's profitability. Thus, hypothesis 5 was developed:

- H5a: The Green Innovation effort $\left(\mathrm{GI}_{1}\right)$ of companies in the industrial sector of DC and EC are positively related to their financial performance.

- H5b: The Green Innovation effort $\left(\mathrm{GI}_{2}\right)$ of companies in the industrial sector of DC and EC are positively related to their financial performance.

From the definition of search hypotheses, it defined the conceptual model of this study, showing relationships between variables, as shown in Figure 1.

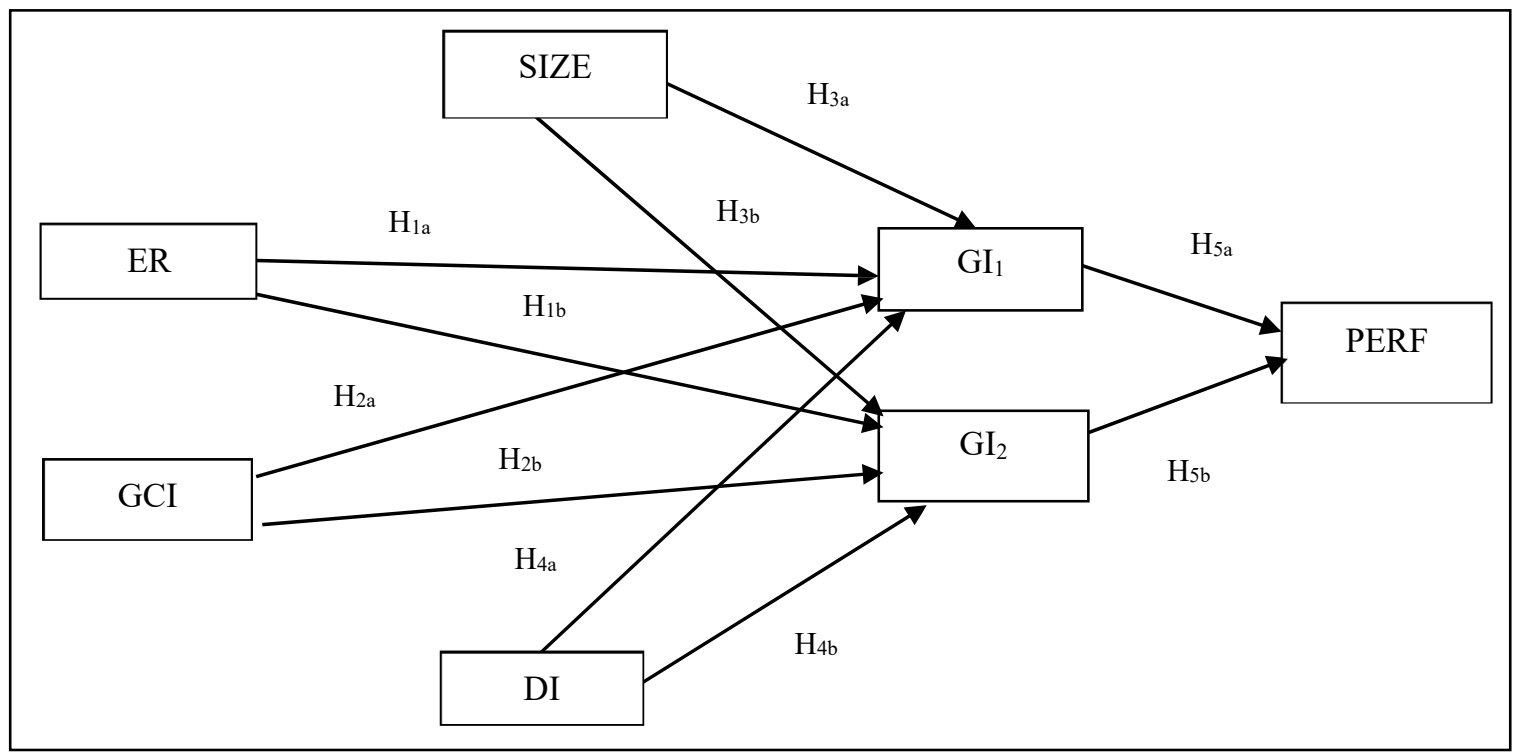

Figure 1. Conceptual Model.

Source: Prepared by the author.

Considering the information above, it appears that many perspectives are considered when addressing Green Innovation, however, although the literature on this topic is vast, the results found can still be considered contradictory and of possible dispute.

\section{METHODOLOGY}

\subsection{Sample and Data Collection}

This study used cross-sectional secondary data with consolidated information from 2015, involving different sources. 
i. Ranking of the 500 largest companies by the market value of the Financial Times of 2015.

ii. Historical database of the Global Competitiveness Index (GCI) of the World Economic Forum (WEF) to measure the institutional environment of countries;

iii. OECD environmental indicators (Rigor of Environmental Policies and environment revenue) to measure the rigor of environmental policies;

iv. List of companies that are signatories to the United Nations Global Compact (UN) to verify those committed to the best business practices that aim to promote sustainable growth and citizenship.

v. Data Stream Database, which belongs to Thomson Reuters for foreign ownership indicators (Degree of Internationalization), company size (Market Value, Sales, Assets and Number of Employees), performance (ROA and ROE) and the Green Innovation variable Environmental Investments.

vi.Analysis of sustainability reports available by companies to verify whether they are based on the GRI (Global Reporting Initiative) guidelines and to verify the adoption of ISO 14001 certification.

vii. List of companies analyzed by RobecoSam that makes up the Dow Jones Sustainability Index (DJSI).

In this step, we initially sought a sample of the 500 largest companies by market value that appeared in the Financial Times in 2015. As the objective of the study includes analyzing and comparing the industrial companies of DC and EC, the 20 largest companies were chosen in each country that makes up the G7 (Group of Seven) to represent developed countries, and the 20 largest companies in each country that make up the BRICS to represent developing countries. From that, we selected only the companies that had all the necessary information to complete the model of the article, according to the variables of the study, having a final sample composed of 159 companies, being $96 \mathrm{DC}$ and $63 \mathrm{EC}$.

\subsection{Model Variables}

According to the proposed conceptual model, the verification of the relationship between the degree of severity of environmental regulations and the international competitiveness of countries with Green Innovation practices and the financial performance of multinational companies in the industrial sector of DC and EC used the following variables:

- Environmental Regulations: In order to measure countries' environmental regulations, a factor analysis was carried out based on two OECD indicators: (a) Environmental Policy Rigor Index (RPA) and (b) Environment-related tax revenue index (RMA), measured by GDP (Gross Domestic Product), generating a single factor to measure the rigor of countries' environmental regulations.

- Institutional Environment: To measure the level of competitiveness of countries, the WEF Global Competitiveness Index (GCI) was used. The GCI is the main ingredient of the Global Competitiveness Report (GCR), which is a comprehensive assessment of the competitiveness of countries developed by WEF's Global Competitiveness Network (GCN). The GCI provides a weighted average of more than 100 different variables, in which each variable is considered to reflect an aspect of competitiveness. About two-thirds of this data comes from the Executive Opinion Survey (EOS), and a third comes from publicly available sources, such as the World Bank, the World Health Organization (WHO) and UNESCO. 
BBR

17

566

- Size and Internationalization: The size of the companies analyzed in the study was composed of four different dimensions: Market Value, Total Sales, Total Assets and Number of Employees. These measures were combined and, based on factor analysis, a factor was generated to measure the size of the companies. This variable is widely used by several authors who have shown that the size of companies sometimes interferes with the conditions for the development of Green Innovation (Lustosa, 2002; Sueyoshi \& Goto, 2009; Weng et al., 2015; Jakobsen \& Clausen, 2016; Amores-Salvadó et al., 2015; Souza et al., 2016).

In this research, the ratio between External Sales in relation to Total Sales or Foreign Sales to Total Sales (FSTS) was used to measure the degree of internationalization of companies. This procedure has already been used in several internationalization studies in the area of international business (Grant, 1987; Qian, 1998; Ruigrok \& Wagner, 2003; Capot \& Kotabe, 2003; Rubashkina et al., 2015; Chen et al., 2006). Although several recent studies question the effectiveness of this measure (Hennart, 2011), research on the topic continues to use this measure since external sales data are available from secondary sources, making it easier to compare companies (Gaur \& Kumar, 2009).

- Green Innovation: For the research, five dummy variables were selected to measure the companies' Green Innovation practices, and like the regulation and size variables, these measures were combined and, from the factorial analysis, two factors were generated to measure the Green Innovation of the companies under study. Factor 1 is composed of the GRI variables and ISO 14001 certification, called GI, and Factor 2 is composed of the variables Global Compact, DJSI and Environmental Investments, called GI .

- Financial Performance: To measure the financial performance of the companies, a factor analysis was carried out using the ROA (Return on Assets) and ROE (Return on Equity) indicators, generating a single factor.

Table 1 shows the variables of the model, the forms of measurement, the authors who have already used these variables and the source of data described in section 3.1: 
Table 1

Definitions of model variables

\begin{tabular}{|c|c|c|c|c|}
\hline Variables & Acronyms & Measurement Form & Authors & Source \\
\hline $\begin{array}{l}\text { Environmental } \\
\text { Regulations }\end{array}$ & ER & $\begin{array}{l}\text { Factorial analysis of the OECD } \\
\text { IEP and IET indicators }\end{array}$ & - & OECD \\
\hline $\begin{array}{l}\text { Global } \\
\text { Competitiveness } \\
\text { Index }\end{array}$ & GCI & GCI & - & $\begin{array}{c}\text { WEF } \\
\text { Competitiveness } \\
\text { Report }\end{array}$ \\
\hline Size & SIZE & $\begin{array}{l}\text { Factorial Analysis of the } \\
\text { variables Market } \\
\text { Value, Total Sales, Total Assets } \\
\text { and Number of Employees. }\end{array}$ & $\begin{array}{l}\text { (7); (9); (13); (17); } \\
\text { (18); (20); (21) }\end{array}$ & $\begin{array}{l}\text { Data Stream } \\
\text { Thomson Reuters }\end{array}$ \\
\hline $\begin{array}{c}\text { Degree of } \\
\text { Internationalization }\end{array}$ & DI & External Sales / Total Sales & $\begin{array}{l}\text { (1); (2); (3); (4); } \\
\text { (10); (19); (22) }\end{array}$ & $\begin{array}{c}\text { Data Stream } \\
\text { Thomson Reuters }\end{array}$ \\
\hline Performance & PERF & $\begin{array}{c}\text { Factorial Analysis of the } \\
\text { variables } \\
\text { ROA and ROE }\end{array}$ & - & $\begin{array}{c}\text { Data Stream } \\
\text { Thomson Reuters }\end{array}$ \\
\hline \multirow{5}{*}{ Green Innovation } & \multirow{2}{*}{$\mathrm{GI}_{1}$} & ISO 14001 & $\begin{array}{c}\text { (5); (6); (8); } \\
\text { (11); (14); (15) }\end{array}$ & $\begin{array}{l}\text { Sustainability } \\
\text { Reports and } \\
\text { Company } \\
\text { Website }\end{array}$ \\
\hline & & GRI & (11); (12); (14) & $\begin{array}{c}\text { GRI Website and } \\
\text { Company } \\
\text { Website }\end{array}$ \\
\hline & \multirow{3}{*}{$\mathrm{GI}_{2}$} & UN Global Compact & - & $\begin{array}{c}\text { UN Global } \\
\text { Compact Website }\end{array}$ \\
\hline & & DJSI & (16) & RobecoSam \\
\hline & & Environmental Investments & (16) & $\begin{array}{c}\text { Data Stream } \\
\text { Thomson Reuters }\end{array}$ \\
\hline
\end{tabular}

Note: (1) Grant (1987); (2) Qian (1998); (3) Ruigrok \& Wagner (2003); (4) Capar \& Kotabe (2003); (5) Barla (2007); (6) Gibson \& Tierney (2011); (7) Aguilera-Caracuel, Hurtado-Torres, \& Aragón-Correa (2012); (8) Feldman (2012); (9) Aguilera-Caracuel \& Ortiz-de-Mondojana (2013); (10) Chiarvesio et al., (2013); (11) Akisik \& Gal (2014); (12) Fernandez-Feijoo, Romero, \& Ruiz (2014); (13) Ghisetti \& Rennings (2014); (14) Amran et al., (2015); (15) Colares et al., (2015); (16) Kim (2015); (17) Lee \& Min (2015); (18) Jabbour et al., (2015); (19) Rubashkina et al., (2015); (20) Amores-Salvadó et al., (2015); (21) Jakobsen \& Clausen (2016); (22) Chen et al., (2016).

\subsection{Data ANALYsis}

Initially, the existence of outliers was verified and then normality (Dubey et al., 2016). To identify the existence of outliers, the standardized z-score method was applied, and to reduce the influence of the identified outliers, the values were treated using winsorization, which consists of an outliers treatment technique developed by Barnett and Lewis (1994).

In addition to the outliers treatment, multidimensional normality was also verified using the Mardia test, Henze-Zirkler test and Doornik-Hansen test, and from the asymmetry (Sk) and kurtosis coefficients, it was verified that none of the variables showed violations to the normal distribution $(|\mathrm{Sk}|<3$ and $|\mathrm{Ku}|<10)$ (Marôco, 2010). To ensure that there was no multicollinearity between the variables, the correlation matrix was examined and all variables had a correlation index less than 0.8 , suggesting that there is no multicollinearity problem. 
BBR

17

568

To analyze the hypotheses of the research model, the data was tested with Structural Equation Modeling (SEM), using Partial Minimum Squares (PLS), also called Path Modeling or PLS Modeling (PLS_PM) with support for the SmartPLS 3.0 software. SEM has the advantage of allowing simultaneous analysis of the relationships between several variables (Hair et al., 2005), in addition to allowing researchers to test more complex conceptual structures, ensuring a more robust analysis of the Dice.

For this study, it followed two steps recommended by Peng and Lai (2012), examining the validity and reliability of the measurement model and analyzing the structural model.

\section{RESULTS AND DISCUSSIONS}

\subsection{Measurement Model Analysis}

For the evaluation of the measurement model, the Confirmatory Factor Analysis (CFA) was used in order to assess the validity of the model constructs. After verifying the factorial loads of the measurement model, the reliability of each item of the construct was examined by means of the composite reliability (CC), the convergent validity through the mean percentage of explained variance (AVE) and the discriminant validity of the measures associated with each construct, obtained from the square root of the AVE value diagonally and the correlation of the respective constructs.

Table 2 provides an overview of the factorial loads, composite reliability (CR) and average variance extracted (AVE) of the constructs. The results show that the factor loads were all greater than 0.5 , the CCs of all constructs were greater than 0.7 and the AVE for each construct was greater than 0.5 (Peng \& Lai 2012). These are the values recommended as ideal, demonstrating that all constructs of the model have a sufficient degree of convergent validity.

Table 2

Factor loads, Composite Reliability and Variance of the variables in the measurement model

\begin{tabular}{|c|c|c|c|c|c|c|}
\hline Constructs & Variables & $\begin{array}{l}\text { Factorial } \\
\text { Loading }\end{array}$ & SD & $\mathrm{p}$-value & SCR & AVE \\
\hline \multirow[t]{4}{*}{ SIZE } & MV & 0.891 & 0.018 & 0.000 & 0,900 & 0,696 \\
\hline & TS & 0.923 & 0.012 & 0.000 & & \\
\hline & TA & 0.850 & 0.030 & 0.000 & & \\
\hline & Employ & 0.644 & 0.060 & 0.000 & & \\
\hline \multirow[t]{2}{*}{ ER } & EP & 0.991 & 0.008 & 0.000 & 0,841 & 0,732 \\
\hline & ET & 0.694 & 0.074 & 0.000 & & \\
\hline \multirow[t]{2}{*}{ GI 1} & ISO & 0.749 & 0.307 & 0.015 & 0,831 & 0,714 \\
\hline & GRI & 0.930 & 0.247 & 0.000 & & \\
\hline \multirow[t]{3}{*}{ GI2 } & GC & 0.819 & 0.113 & 0.000 & 0,758 & 0,612 \\
\hline & DJSI & 0.743 & 0.148 & 0.000 & & \\
\hline & EI & 0.891 & 0.018 & 0.000 & 0,900 & 0,696 \\
\hline \multirow[t]{2}{*}{ PERF } & ROA & 0.977 & 0.081 & 0.000 & 0,761 & 0,631 \\
\hline & ROE & 0.553 & 0.098 & 0.000 & & \\
\hline
\end{tabular}

Note: MV - Market Value; TS - Total Sales; TA - Total assets; Employ - Number of employees; ER - Environmental Regulations; EP - Environmental Policies; ET - Environment Tax; GI - Green Innovation 1; GI - Green Innovation 2; GC - Global Compact; EI - Environmental Investments; ISO - ISO14001 certification; GRI - Global Reporting Initiative; PERF - Performance; ROA - Return on Assets; ROE - Return on Equity. 
Table 3 shows the correlations between the paired constructs, and the main diagonal of the matrix shows the square root of the stroke of each construct. All measures indicate adequate discriminant validity (Fornell \& Larcker, 1981; Peng \& Lai, 2012).

Table 3

Discriminant Validity of the Measure Model

\begin{tabular}{cccccc}
\hline & SIZE & ER & GI $_{1}$ & $\mathrm{GI}_{2}$ & PERF \\
\hline SIZE & $\mathbf{0 . 8 3 4}$ & & & & \\
ER & 0.254 & $\mathbf{0 . 8 5 6}$ & & & \\
$\mathrm{GI}_{1}$ & 0.069 & -0.174 & $\mathbf{0 . 8 4 5}$ & & \\
$\mathrm{GI}_{2}$ & 0.222 & 0.031 & 0.268 & $\mathbf{0 . 7 8 2}$ & \\
PERF & -0.097 & -0.114 & -0.182 & -0.107 & $\mathbf{0 , 7 9 4}$ \\
\hline
\end{tabular}

Source: Research data.

\subsection{Structural Model Analysis}

After the analysis and validation of the measurement model, the analysis of the structural model was performed through the analysis of trajectories with latent variables. Table 4 shows the coefficient of the structural model and the statistical significance of these coefficients with the analysis of the hypotheses.

Table 4

Results of the structural model with analysis of the hypotheses

\begin{tabular}{clcccc}
\hline Hypotheses & Variables & structural coefficient & SD & p-value & Decision \\
\hline $\mathbf{H}_{\mathbf{1}}$ & $\mathrm{ER} \rightarrow \mathrm{IGI}_{1}$ & -0.178 & 0.194 & 0.358 & Reject \\
$\mathbf{H}_{\mathbf{1 b}}$ & $\mathrm{ER} \rightarrow \mathrm{IGI}_{2}$ & 0.209 & 0.106 & 0.050 & Accept \\
$\mathbf{H}_{2 \mathbf{a}}$ & $\mathrm{GCI} \rightarrow \mathrm{IGI}_{1}$ & -0.086 & 0.171 & 0.616 & Reject \\
$\mathbf{H}_{\mathbf{2}}$ & $\mathrm{GCI} \rightarrow \mathrm{IGI}_{2}$ & -0.404 & 0.132 & 0.002 & Reject \\
$\mathbf{H}_{3 \mathbf{a}}$ & $\mathrm{SIZE} \rightarrow \mathrm{IGI}_{1}$ & 0.163 & 0.124 & 0.190 & Reject \\
$\mathbf{H}_{3 \mathbf{b}}$ & $\mathrm{SIZE} \rightarrow \mathrm{IGI}_{2}$ & 0.431 & 0.093 & 0.000 & Accept \\
$\mathbf{H}_{4 \mathbf{a}}$ & $\mathrm{DI} \rightarrow \mathrm{IGI}_{1}$ & 0.137 & 0.139 & 0.462 & Reject \\
$\mathbf{H}_{4 \mathbf{b}}$ & $\mathrm{DI} \rightarrow \mathrm{IGI}_{2}$ & 0.143 & 0.081 & 0.078 & Reject \\
$\mathbf{H}_{5 \mathbf{a}}$ & $\mathrm{GI}_{1} \rightarrow \mathrm{IPERF}$ & 0.027 & 0.100 & 0.938 & Reject \\
$\mathbf{H}_{5 \mathbf{b}}$ & $\mathrm{GI}_{2} \rightarrow \mathrm{IPERF}$ & -0.489 & 0.059 & 0.000 & Reject \\
\hline
\end{tabular}

Source: Research data.

Ascertaining the relationships between the variables demonstrated by the structural coefficients, it was found that four relationships showed statistical significance $(\mathrm{p}<0.05)$. The relationship between the ER and $\mathrm{GI}_{2}$ constructs (coefficient 0.209; $\mathrm{p}=0.05$ ) is significant and confirmed the $\mathrm{H}_{1 \mathrm{~b}}$ hypothesis. Likewise, the relationship between SIZE and $\mathrm{GI}_{2}$ (coefficient $0.431 ; \mathrm{p}=0.000$ ) also showed statistical significance, corroborating the $\mathrm{H}_{\mathrm{b} 3}$ hypothesis. The relationship between GCI and $\mathrm{GI}_{2}$ (coefficient -0.404; $\mathrm{p}=0.002$ ), despite having presented statistical significance, demonstrated a negative relationship and did not confirm $\mathrm{H}_{2 \mathrm{~b}}$. As well as the relationship between GCI and $\mathrm{GI}_{2}$, the relationship between $\mathrm{GI}_{2}$ and PERF was statistically significant, however, 
BBR

17

570

$\mathrm{GI}_{2}$ had a negative impact on the companies' PERF (coefficient $-0.489 ; \mathrm{p}=0.000$ ) without confirming $\mathrm{H}_{5 \mathrm{~b}}$.

After evaluating the structural coefficients of the relationships between the latent variables, it is necessary to verify the predictive capacity of the model, measured by $\mathrm{R}^{2}$. $\mathrm{R}^{2}$ specifies the percentage of the total $Y$ variation explained by the regression model (Hair et al., 2005). According to Cohen's (2009) criterion for social and behavioral sciences, $\mathrm{R}^{2}$ can be considered average for the $\mathrm{GI}_{2}$ construct $\left(\mathrm{R}^{2}>0.13\right)$ and it can have a great effect on the SIZE and GCI constructs $\left(\mathrm{R}^{2}\right.$ $>0.26$ ), as shown in Table 5. For the GI1 variable, the $\mathrm{R}^{2}$ of 0.085 allows us to conclude that the four latent variables tested explain only $8.5 \%$ of their variance. Regarding the DI variable $\left(\mathrm{R}^{2}=0.102\right)$, the GCI and ER variables explain only $10.2 \%$ of their variance. Also, the PERF variable $\left(\mathrm{R}^{2}=0.079\right)$, the variables $\mathrm{GI}_{1}$ and $\mathrm{GI}_{2}$ explain only $7.9 \%$ of their variance.

Table 5

Results of the Structural Model

\begin{tabular}{ccccc}
\hline Indicators & $\mathrm{R}^{2}$ & $\mathrm{R} 2$ adjusted & Gof & $\mathrm{f}^{2}$ \\
\hline SIZE & 0.331 & 0.323 & 0.479 & 0.127 \\
$\mathrm{GI}_{1}$ & 0.085 & 0.044 & 0.246 & 0.016 \\
$\mathrm{GI}_{2}$ & 0.176 & 0.138 & 0.328 & 0.015 \\
$\mathrm{GCI}$ & 0.474 & 0.471 & 0.688 & 0.072 \\
$\mathrm{DI}$ & 0.102 & 0.092 & 0.319 & 0.020 \\
PERF & 0.079 & 0.071 & 0.049 & 0.011 \\
\hline
\end{tabular}

Source: Research data.

The adjusted $\mathrm{R}^{2}$, which corrects the effect of the sample size and the number of variables in the equation, present values considered average for the constructs GCI, SIZE and GI (adjusted

$\mathrm{R}^{2}>0.25$ ), and small values for the DI, GI and PERF (adjusted $\mathrm{R}^{2}>0.04$ ), confirming the low explanatory power of latent variables in $\mathrm{GI}_{1}$ and DI. In addition to evaluating these values, two other indicators were considered to verify the quality of the model's fit, effect size $\left(f_{2}\right)$ and Gof. According to Hair et al., (2005), $\mathrm{f}^{2}$ assesses how each construct is useful for adjusting the model. Table 4 shows that all constructs did not present values greater than 0.35 , representing a small effect for the general adjustment of the model.

Finally, the Gof was analyzed as a model adequacy index, and considering the appropriate Gof parameters, it can be observed that for variables $\mathrm{GI}_{1}, \mathrm{GI}_{2}$ and DI the absolute Gof measurements are greater than 0.25 , representing a quality index average. For the PERF variable, the Gof value of 0.049 represents a low-quality index. For the SIZE and GCI variables, their values were greater than 0.36 , representing a greater similarity between the estimated and observed covariance matrices.

\subsection{Discussion}

This study analyzed the relationship between the degree of severity of environmental regulations and the international competitiveness of countries with efforts in Green Innovation, as well as the financial performance of companies in the industrial sector of DC and EC. This analysis was possible through the verification of the relationships between the variables through the Structural Equation Modeling.

As the data used to measure the companies' Green Innovation effort generated two factors (GI and $\mathrm{GI}_{2}$ ), all the relationships between the variables environmental regulations, competitiveness, 
size, degree of internationalization, and performance were performed with construct $\mathrm{GI}_{1}$ and construct $\mathrm{GI}_{2}$ separately.

The empirical results highlight that both environmental regulation and the size of the companies showed a statistically positive and significant relationship with the efforts of companies in Green Innovation, only in construct $\mathrm{GI}_{2}$, confirming the hypotheses $\mathrm{H}_{1 \mathrm{~b}}$ and $\mathrm{H}_{3 \mathrm{~b}}$. Despite the results presenting statistical significance for the construct $\mathrm{GI}_{2}$, they demonstrated a negative relationship between competitiveness and the efforts of Green Innovation, rejecting the hypotheses $\mathrm{H}_{2 \mathrm{a}}$ and $\mathrm{H}_{2 \mathrm{~b}}$.

Considering environmental regulation, the results corroborate other authors (Doran \& Ryan, 2012; Dangelico, 2016; Li, 2014; Huang et al., 2016), who stated that environmental regulations pressure companies to invest in initiatives related to environmental issues.

Regarding the size variable, several studies in the literature have shown that larger companies have better conditions for the development of Green Innovation (Ferraz \& Motta, 2002; AguileraCaracuel, 2013; Weng et al., 2015). Other studies have found no relationship between the size of companies and their commitment to Green Innovation (Horbach, 2012). These surveys used different ways to measure size: some studies used the variable 'volume of assets and financial resources', others used 'number of employees' and 'total net revenue'. The present study used four dimensions to measure the size of companies that could be combined and generate a single size factor related to two constructs of Green Innovation. As the results were divergent for different measures of Green Innovation, this could justify this difference.

The present study also provides an analysis of the relationship between countries' competitiveness and companies' Green Innovation efforts. It was found that the relationship between the countries 'competitiveness and the companies' Green Innovation effort was negative for the two Green Innovation constructs, rejecting $\mathrm{H}_{2 \mathrm{a}}$ and $\mathrm{H}_{2 \mathrm{~b}}$. Despite the GCI $\rightarrow \mathrm{GI}_{2}$ relationship showing statistical significance, the countries' competitiveness indicated a strong and negative influence with companies' Green Innovation effort, which did not support the H2a hypothesis. In other words, market competitiveness is not a precedent for Green Innovation companies, but it can be part of this process of seeking greater competitiveness. This result is in line with the results of Lustosa (2011), who stated that the degree of competition in the market is one of the factors that most influence the decision to generate and adopt innovations, including environmental ones.

Regarding the degree of internationalization, despite the structural coefficients showing a positive effect between the GI and the two constructs of Green Innovation, this relationship did not present a statistically significant influence and it rejected hypotheses $\mathrm{H}_{4 \mathrm{a}}$ and $\mathrm{H}_{4 \mathrm{~b}}$. These results do not corroborate the literature (Cainelli et al., 2011; Guoyou et al., 2013; Chen et al., 2006) because the IM, measured by External Sales/Total Sales, does not encourage the Green Innovation effort of companies in the search for ISO14001 certification, nor in the disclosure of sustainability reports based on GRI guidelines, nor does it encourage environmental investments and the search for voluntary initiatives that promote sustainable growth.

Considering the relationship between Green Innovation and companies' financial performance, the results of the study demonstrated that companies' Green Innovation efforts do not positively affect their financial performance, rejecting hypotheses $\mathrm{H}_{5 \mathrm{a}}$ and $\mathrm{H}_{5 \mathrm{~b}}$. On the contrary, the data shows that companies that make environmental investments and are concerned with initiatives aimed at the environment in their business practices, in the short term, negatively affecting their financial performance. These results differ from what the literature has been presenting on the subject. According to Borsatto and Amui (2018), about 52\% of the studies that analyzed this relationship revealed that there was a positive effect between variables, indicating that ecoinnovative companies are characterized by a higher financial performance (Aguilera-Caracuel 
\& Ortiz-de-Mandojana, 2013; Ghisetti \& Rennings, 2014; Li, 2014; Przchodzen; Przchodzen, 2015; Zailani et al., 2015). However, many studies indicate that there is no direct relationship between Green Innovation and companies' financial performance.

\section{CONCLUSIONS}

This study analyzed the relationship between the degree of severity of environmental regulations and the international competitiveness of countries with efforts in Green Innovation and the financial performance of companies in the industrial sector of DC and EC. In order to achieve this objective, it required the identification of a systematization of the literature on the subject. From the data collected, the relationship between the variables was evaluated through Structural Equation Modeling.

The results showed that the strictness of the environmental regulations of the countries measured, by means of the OECD, RPA and RMA, indicators affect the Green Innovation effort of the industrial companies of DC and EC only in construct GI, composed of the variables Global Compact and environmental investments. In addition, it was also found that the countries' competitiveness, as measured by the WEF GCI, did not have a positive influence on the companies' Green Innovation effort, but rather showed a negative and statistically significant effect on construct $\mathrm{GI}_{2}$. These results diverge from the literature presented (Apak \& Atay, 2015; Lustosa, 2011), demonstrating that competitiveness did not present an antecedent of companies' Green Innovation.

Regarding the size of the companies, the results had a positive and statistically significant impact only on construct $\mathrm{GI}_{2}$, demonstrating that the size of the companies does not interfere in the search for certification or in the disclosure of reports based on the GRI guidelines, but it influences the volume of environmental investments made by companies. The degree of internationalization of the companies did not have a significant effect on any of the Green Innovation constructs, demonstrating that, in this analysis, foreign ownership did not directly affect the Green Innovation efforts of the companies under study. As for the impact on financial performance, it was found that the companies' Green Innovation efforts did not positively impact financial performance, demonstrating a divergence from what has been presented in the literature.

As the results showed significant divergences in relation to the dominant literature in the area, this work contributes shedding light on a "counter-discussion" of this theme, as it has been approached more recently (Lee \& Min, 2015; Dangelico, 2016).

For the Green Innovation literature, these results support theorists who argue that environmental regulations have a positive relationship with the company's sustainability actions (Johnstone et al., 2012; Kesidou \& Demirel, 2012; Doran \& Ryan, 2012; Aguilera-Caracuel \& Ortiz-DeMandojana, 2013; Zailani et al., 2015; Dangelico, 2016; Wang \& Song, 2017). However, these effects may be different depending on how these sustainability actions are measured.

From a managerial point of view, this study suggests that companies are not seeking to improve their environmental management process through certification, nor to release their sustainability reports only to meet the requirements of regulations, but rather to meet the interests of their stakeholders. The strictness of regulations still shapes decisions in terms of environmental investments and voluntary sustainability actions such as the UN Global Compact. In a way, it helps the company's image in the market, but does not reflect positively on companies' financial performance.

This research has some limitations that may generate future studies. Firstly, this study has a sample limitation, that is, as the research was conducted with a non-random sample, it generates 
barriers to the generalization of results beyond the sample. Another limitation was the difficulty of collecting data. As these are several variables from companies from twelve countries and different sources, this made it difficult to search for all variables for each company analyzed, reducing the sample size. Another limitation was the fact that it used cross-sectional data from 2015. Future studies may benefit from data collected over a long period of time. In addition, data obtained through questionnaires and interviews with CEOs and company employees can capture other relevant issues and enrich the work.

Thus, this work contributes to the literature by showing the need for future studies, since there are factors not yet explained, which interfere in the relationship between environmental regulations, Green Innovation, and financial performance., Other studies could consider using other variables to measure both Green Innovation and company performance, besides comparative studies between DC and EC companies. In addition to this contribution, this empirical comparative study with multinational DC and EC companies from different sectors seeks to expand knowledge about the relationships between environmental regulations, Green Innovation and financial performance in different country contexts, addressing the need for advanced literature in this aspect.

\section{REFERENCES}

Aguilera, R.V., D.E. Rupp, C.A. Williams, and J. Ganapathi. 2007. Putting the S back in corporate social responsibility: A multilevel theory of social change in organizations. Academy of Management Review, 32(3): 836-863.

Aguilera-Caracuel, J., Hurtado-Torres, N. E., \& Aragón-Correa, J. A. (2012). Does international experience help firms to be green? A knowledge-based view of how international experience and organisational learning influence proactive environmental strategies. International Business Review, 21(5), 847-861.

Aguilera-Caracuel, J. \& Ortiz-de-Mandojana, N. (2013). Green innovation and financial performance an institutional approach. Organization \& Environment, 26(4), 365-385. https:// doi.org/10.1177/1086026613507931

Akisik, O., \& Gal, G. (2014). Financial performance and reviews of corporate social responsibility reports. Journal of Management Control, 25(3-4), 259-288.

Amores-Salvadó, J., Martín-de Castro, G., \& Navas-López, J. E. (2015). Green corporate image: moderating the connection between environmental product innovation and firm performance. Journal of Cleaner Production, 83, 356-365.

Amran, Y. M., Farzadnia, N., \& Ali, A. A. (2015). Properties and applications of foamed concrete; a review. Construction and Building Materials, 101, 990-1005.

Apak, S., \& Atay, E. (2015). Global competitiveness in the EU through green innovation technologies and knowledge production. Procedia-Social and Behavioral Sciences, 181, 207-217. https://doi. org/10.1016/j.sbspro.2015.04.882

Arenhardt, D. L., Battistella, L. F. \& Franchi, T. S. (2012). A influência da inovação verde na busca de vantagem Competitiva das empresas dos setores elétrico e eletrônico Brasileiro. Encontro da Associação Nacional de Pós-graduação e Pesquisas em Administração. Rio de Janeiro, Brasil, 36.

Balkyte, A. \& Tvaronaviciene, M. (2010). Perception of competitiveness in the context of sustainable development: facets of "sustainable development". Journal of Business Economics and Management, 11(2), 341-365. 
BBR

17

574

Barbieri, J. C., Vasconcelos, I. F. G, Andreassi, T. \& Vasconcelos, F. C. (2010). Inovação e sustentabilidade: novos modelos e proposiçôes. RAE - Revista de Administração de Empresas, 50(2), 146-154. http:// dx.doi.org/10.1590/S0034-75902010000200002

Barla, P. (2007). ISO 14001 certification and environmental performance in Quebec's pulp and paper industry. Journal of environmental economics and management, 53(3), 291-306.

Barnett, V. \& Lewis, T. (1994). Outliers in Statistical Data. (3rd ed.). Hoboken, NJ: Wiley.

Bernauer, T., Engels, S., Kammerer, D. \& Seijas, J. (2006). Explaining green innovation. Center for Comparative and International Studies (CIS), ETH Zurich, University of Zurich, working paper, n. 17, $1-16$.

Borsatto, J.M.L.S. \& Amui, L.B.L. (2018, Outubro). Inovação Verde e Desempenho: Uma Revisão Sistemática de Trabalhos Acadêmicos Internacionais. Anais do XLII Encontro da Associação Nacional de Pós-Graduação e Pesquisa em Administração, Curitiba, PR, Brasil.

Cai, Y., Lu, Y., Stegman, A., \& Newth, D. (2017). Simulating emissions intensity targets with energy economic models: algorithm and application. Annals of Operations Research, 255(1-2), 141-155.

Cainelli, G., Mazzanti, M., \& Zoboli, R. (2011). Environmental innovations, complementarity and local/global cooperation: evidence from North-East Italian industry. International Journal of Technology, Policy and Management, 11(3-4), 328-368.

Capar, N., \& Kotabe, M. (2003). The relationship between international diversification and performance in service firms. Journal of International Business Studies, 34(4), 345-355.

Carpes, A. M., Santos, M. B., Borges, D. E. \& Scherer, F. L. (2012). A internacionalização aliada a sustentabilidade: levantamento do panorama nacional e internacional. In: Encontro Internacional sobre Gestão Empresarial e Meio Ambiente. São Paulo, Brasil, 14.

Chen, Y-S., Lai, S-B. \& Wen, C-T. (2006). The influence of green innovation performance on corporate advantage in Taiwan. Journal of Business Ethics, 67(4), 331-339. https://doi.org/10.1007/ s10551-006-9025-5

Chen, Y. S., Chang, C. H., \& Wu, F. S. (2012). Origins of green innovations: the differences between proactive and reactive green innovations. Management Decision, 50(3), 368- 398.

Chiarvesio, M., Di Maria, E., \& Micelli, S. (2013). Sourcing from Northern and Southern Countries: The global value chain approach applied to Italian SMEs. Transition Studies Review, 20(3), 389-404.

Colares, A. C. V., Athayde, M., da Cunha, J. V. A., \& de Souza Ribeiro, M. (2015). As Empresas com Certificação ISO 14001 Realmente têm uma Atividade Ambiental Superior? Sistemas \& Gestão, 10(3), 356-368.

Dangelico, R. M. \& Pujari, D. (2010). Mainstreaming green product innovation: Why and how companies integrate environmental sustainability. Journal of Business Ethics, 95(3), 471-486. https:// doi.org/10.1007/s10551-010-0434-0

Dangelico, R. M. (2016). Green product innovation: where we are and where we are going. Business Strategy and the Environment, 25(8), 560-576.

Davila, T., Epstein, M. J. \& Shelton, R. (2006). As regras da Inovação. Como gerenciar, como medir e como lucrar. Porto Alegre: Bookman.

DiMaggio, P. J., \& Powell, W. W. (1983). The iron cage revisited: Institutional isomorphism and collective rationality in organizational fields. American Sociological Review, 48(20, 147-160). 
Doran, J. \& Ryan, G. (2012). Regulation and firm perception, eco-innovation and firm performance. European Journal of Innovation Management, 15(4), 421- 441. https://doi. org/10.1108/14601061211272367

Dubey, R., Gunasekaran, A., Childe, S. J., Papadopoulos, T., Hazen, B., Giannakis, M., \& Roubaud, D. (2017). Examining the effect of external pressures and organizational culture on shaping performance measurement systems (PMS) for sustainability benchmarking: Some empirical findings. International Journal of Production Economics, 193, 63-76.

Dubey, R., Gunasekaran, A., Childe, S. J., Papadopoulos, T., Wamba, S. F., \& Song, M. (2016). Towards a theory of sustainable consumption and production: Constructs and measurement. Resources, Conservation and Recycling, 106, 78-89.

Eiadat, Y. Kelly, A., Roche, F. \& Eyadat, H. (2008). Green and competitive? An empirical test of the mediating role of environmental innovation strategy. Journal of World Business, 43(2), 131-145. https://doi.org/10.1016/j.jwb.2007.11.012

Feldman, I. R. (2012). ISO standards, environmental management systems, and ecosystem services. Environmental Quality Management, 21(3), 69-79.

Fernandez-Feijoo, B., Romero, S., \& Ruiz, S. (2014). Effect of stakeholders' pressure on transparency of sustainability reports within the GRI framework. Journal of Business Ethics, 122(1), 53-63.

Ferraz, C., \& Motta, R. S. D. (2002). Regulação, mercado ou pressão social?: os determinantes do investimento ambiental na indústria. Rio de Janeiro: IPEA. http://repositorio.ipea.gov.br/handle/11058/2096

Fornell, C., \& Larcker, D. F. (1981). Evaluating structural equation models with unobservable variables and measurement error. Journal of Marketing Research, 18(1), 39-50.

Gaur, A. S., \& Kumar, V. (2009). International diversification, business group affiliation and firm performance: Empirical evidence from India. British Journal of Management, 20(2), 172-186.

Gauthier, J. \& Wooldridge, B. (2012). Influences on Sustainable Innovation Adoption: Evidence from Leadership in Energy and Environmental Design. Business Strategy and The Environment, 21(2), 98-110. https://doi.org/10.1002/bse.716

Ghisetti, C., \& Rennings, K. (2014). Environmental innovations and profitability: how does it pay to be green? An empirical analysis on the German innovation survey. Journal of Cleaner Production, $75,106-117$.

Gibson, K., \& Tierney, J. M. (2011). The evolution of environmental management systems: Back to basics. Environmental Quality Management, 21(1), 23-37.

Gordon, I. R. \& McCann, P. (2005). Innovation, agglomeration, and regional development. Journal of Economic Geography, 5(5), 523-543. https://doi.org/10.1093/jeg/lbh072

Grant, Robert M. (1987). Multinationality and performance among British manufacturing companies. Journal of international business studies, 18(3), 79-89.

Guoyou, Q., Saixing, Z., Chiming, T., Haitao, Y., \& Hailiang, Z. (2013). Stakeholders' influences on corporate green innovation strategy: a case study of manufacturing firms in China. Corporate Social Responsibility and Environmental Management, 20(1), 1-14.

Hair, J., Babin, B., Money, A., \& Samouel, P. (2005). Fundamentos de métodos de pesquisa em administração. Porto Alegre: Bookman.

Hennart, J. F. (2011). A theoretical assessment of the empirical literature on the impact of multinationality on performance. Global Strategy Journal, 1(1-2), 135-151. 
BBR

17

576

Herciu, M. \& Ogrean, C. (2014). An Overview on European Union Sustainable Competitiveness. Procedia Economics and Finance, 16, 651-656. https://doi.org/10.1016/S2212-5671(14)00853-3

Horbach, J., Rammer, C., \& Rennings, K. (2012). Determinants of eco-innovations by type of environmental impact - The role of regulatory push/pull, technology push and market pull. Ecological economics, 78, 112-122.

Huang, X. X., Hu, Z. P., Liu, C. S., Yu, D. J., \& Yu, L. F. (2016). The relationships between regulatory and customer pressure, green organizational responses, and green innovation performance. Journal of Cleaner Production, 112, 3423-3433.

Jabbour, A. B. L., de Oliveira Frascareli, F. C., \& Jabbour, C. J. C. (2015). Green supply chain management and firms' performance: Understanding potential relationships and the role of green sourcing and some other green practices. Resources, Conservation and Recycling, 104, 366-374.

Jakobsen, S., \& Clausen, T. H. (2016). Innovating for a greener future: the direct and indirect effects of firms' environmental objectives on the innovation process. Journal of Cleaner Production, 128, 131-141.

Johnstone, N., Haščič, I., Poirier, J., Hemar, M., \& Michel, C. (2012). Environmental policy stringency and technological innovation: evidence from survey data and patent counts. Applied Economics, 44(17), 2157-2170.

Kesidou, E., \& Demirel, P. (2012). On the drivers of eco-innovations: Empirical evidence from the UK. Research Policy, 41(5), 862-870.

Kim, Y. (2015). Environmental, sustainable behaviors and innovation of firms during the financial crisis. Business Strategy and the Environment, 24(1), 58-72.

Lee, C., \& Chew-Ging, L. (2007). Encouraging innovation in Malaysia. CACCI Journal, 1, 1-8.

Lee, K. H., \& Min, B. (2015). Green R\&D for eco-innovation and its impact on carbon emissions and firm performance. Journal of Cleaner Production, 108, 534-542.

Li, Y. (2014). Environmental innovation practices and performance: moderating effect of resource commitment. Journal of Cleaner Production, 66, 450-458. https://doi.org/10.1016/j. jclepro.2013.11.044

Link, S. \& Naveh, E. (2006). Standardization and discretion: Does the environmental standard ISO 14001 lead to performance benefits? IEEE Transactions on Engineering Management, 53(4), 508519. https://doi.org/10.1109/tem.2006.883704

Lustosa, M. C. J. (2002). Meio ambiente, inovação e competitividade na indústria brasileira: a cadeia produtiva do petróleo. [Doctoral dissertation] - Instituto de Economia, Universidade Federal do Rio de Janeiro. Rio de Janeiro, Brasil.

Lustosa, M. C. J. (2010). Industrialização, meio ambiente, inovação e competitividade. (pp. 205-220) In: Peter May. (Org.). Economia e Meio Ambiente: teoria e prática. 2nd ed. Rio de Janeiro: Elsevier.

Lustosa, M. C. J. (2011). Inovação e tecnologia para uma economia verde: questôes fundamentais. Politica Ambiental, 8, 111-122.

Marôco, J. (2010). Análise de equaçóes estruturais: Fundamentos teóricos, software \& aplicaçóes. Lisboa: Report Number.

Mintzberg, H. , Lampel, J. \& Quinn, J. B. (2003). The strategy process: concepts, contexts, cases. Prentice-Hall. 
Ntim, C. G. (2016). Corporate governance, corporate health accounting, and firm value: The case of HIV/AIDS disclosures in Sub-Saharan Africa. The International Journal of Accounting, 51(2), $155-216$.

Ntim, C. G., \& Soobaroyen, T. (2013). Corporate governance and performance in socially responsible corporations: New empirical insights from a Neo-Institutional framework. Corporate Governance: An International Review, 21(5), 468-494.

Peng, D. X., \& Lai, F. (2012). Using partial least squares in operations management research: A practical guideline and summary of past research. Journal of Operations Management, 30(6), 467-480.

Podcameni, M. G. V. B. (2007) Meio Ambiente, Inovação e competitividade: uma análise da indústria de transformação brasileira com ênfase no setor de combustivel. [Master thesis]. Instituto de Economia, Universidade Federal do Rio de Janeiro. Rio de Janeiro, Brasil.

Porter, M. E. \& van der Linde, C. (1995). Toward a New Conception of the EnvironmentCompetitiveness Relationship. Journal of Economic Perspectives, 9(4), 97-118.

Porter, M. E. (1989). Vantagem competitiva: criando e sustentando um desempenho superior. Rio de Janeiro: Campus.

Porter, M., \& van der Linde, C. (1995). Green and competitive: ending the stalemate. Harvard Business Review, 1995, 120-134. https://hbr.org/1995/09/green-and-competitive-ending-the-stalemate

Przychodzen, J., \& Przychodzen, W. (2015). Relationships between eco-innovation and financial performance-evidence from publicly traded companies in Poland and Hungary. Journal of Cleaner Production, 90, 253-263.

Pujari, D. (2006). Eco-innovation and new product development: understanding the influences on market performance. Technovation, 26(1), 76-85. https://doi.org/10.1016/j.technovation.2004.07.006

Qian, G. (1998). Determinants of profit performance for the largest US firms 1981-92. Multinational Business Review, 6(2), 44.

Ren, S., Li, X., Yuan, B., Li, D., \& Chen, X. (2018). The effects of three types of environmental regulation on eco-efficiency: A cross-region analysis in China. Journal of cleaner production, 173, 245-255.

Rentizelas, A., de Sousa Jabbour, A. B. L., Al Balushi, A. D., \& Tuni, A. (2020). Social sustainability in the oil and gas industry: institutional pressure and the management of sustainable supply chains. Annals of Operations Research, 290, 279-300.

Rubashkina, Y., Galeotti, M., \& Verdolini, E. (2015). Environmental regulation and competitiveness: Empirical evidence on the Porter Hypothesis from European manufacturing sectors. Energy Policy, 83, 288-300.

Ruigrok, W., \& Wagner, H. (2003). Internationalization and performance: An organizational learning perspective. Management International Review, 43(1), 63-84.

Sarkis, J., PilarGonzalez-Torre, P. \& Adenso-Diaz, B. (2010). Stakeholder pressure and the adoption of environmental practices: The mediating effect of training. Journal of Operations Management, 28(2), 163-176, 2010. https://doi.org/10.1016/j.jom.2009.10.001

Scott, R. W. (2001). Institutions and Organizations: Ideas, Interests, and Identities. Thousand Oaks: SAGE. 
BBR

17

578
Seles, B. M. R. P., de Sousa Jabbour, A. B. L., Jabbour, C. J. C., \& Dangelico, R. M. (2016). The green bullwhip effect, the diffusion of green supply chain practices, and institutional pressures: Evidence from the automotive sector. International Journal of Production Economics, 182, 342-355.

Souza, T. R. D., Brighenti, J., \& Hein, N. (2016). Investimentos ambientais e desempenho econômicofinanceiro das empresas brasileiras listadas no índice de sustentabilidade empresarial-ISE. Revista Reuna, 21(2), 97-114.

Sueyoshi, T., \& Goto, M. (2009). Can environmental investment and expenditure enhance financial performance of US electric utility firms under the clean air act amendment of 1990?. Energy Policy, $37(11), 4819-4826$.

Wang, S., \& Song, M. (2017). Influences of reverse outsourcing on green technological progress from the perspective of a global supply chain. Science of the Total Environment, 595, 201-208. https:// doi.org/10.1016/j.scitotenv.2017.03.243

Weng, H. H. R., Chen, J. S., \& Chen, P. C. (2015). Effects of green innovation on environmental and corporate performance: A stakeholder perspective. Sustainability, 7(5), 4997-5026.

Xie, X., Huo, J., Qi, G., \& Zhu, K. X. (2015). Green process innovation and financial performance in emerging economies: Moderating effects of absorptive capacity and green subsidies. IEEE Transactions on Engineering Management, 63(1), 101-112.

Zailani, S., Govindan, K., Iranmanesh, M., Shaharudin, M. R. \& Chong, Y. S. (2015). Green innovation adoption in automotive supply chain: the Malaysian case. Journal of Cleaner Production, 108, 1115-1122. https://doi.org/10.1016/j.jclepro.2015.06.039

Zhu, Q., \& Sarkis, J. (2007). The moderating effects of institutional pressures on emergent green supply chain practices and performance. International journal of production research, 45(18-19), 4333-4355. https://doi.org/10.1080/00207540701440345

\section{AUTHOR'S CONTRIBUTION}

JMLSB: Research Development, Data Analysis, Final Review; CB: Contribution to the contextualization of the theme, Literature Review and Final Review; LA: Research Guidance, Final Review.

\section{CONFLICTS OF INTEREST}

I declare that there are no conflicts of interest in submitting this article. (JMLSB) 